\title{
Effect of wind speed on aerosol optical depth over remote oceans, based on data from the Maritime Aerosol Network
}

\author{
A. Smirnov ${ }^{1,2}$, A. M. Sayer ${ }^{2,3}$, B. N. Holben ${ }^{2}$, N. C. Hsu ${ }^{2}$, S. M. Sakerin ${ }^{4}$, A. Macke ${ }^{5}$, N. B. Nelson ${ }^{6}$, Y. Courcoux ${ }^{7}$,

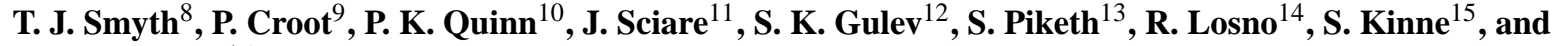 \\ V. F. Radionov ${ }^{16}$ \\ ${ }^{1}$ Sigma Space Corporation, Lanham, Maryland, USA \\ ${ }^{2}$ NASA Goddard Space Flight Center, Greenbelt, Maryland, USA \\ ${ }^{3}$ Goddard Earth Science Technology and Research - GESTAR, Columbia, Maryland, USA \\ ${ }^{4}$ Institute of Atmospheric Optics, Tomsk, Russia \\ ${ }^{5}$ Leibniz Institute for Tropospheric Research, Leipzig, Germany \\ ${ }^{6}$ University of California, Santa Barbara, California, USA \\ ${ }^{7}$ Université de la Réunion, Saint Denis de la Réunion, France \\ ${ }^{8}$ Plymouth Marine Laboratory, Plymouth, UK \\ ${ }^{9}$ Leibniz Institute of Marine Sciences, Kiel, Germany \\ ${ }^{10}$ NOAA PMEL, Seattle, Washington, USA \\ ${ }^{11}$ Laboratoire des Sciences du Climat et de l'Environnement, Gif-sur-Yvette, France \\ ${ }^{12}$ P. P. Shirshov Institute of Oceanology, Moscow, Russia \\ ${ }^{13}$ University of the Witwatersrand, Johannesburg, South Africa \\ ${ }^{14}$ Université de Paris7 et Université de Paris 12, Creteil, France \\ ${ }^{15}$ Institute for Meteorology, University of Hamburg, Hamburg, Germany \\ ${ }^{16}$ Arctic and Antarctic Research Institute, Saint Petersburg, Russia
}

Correspondence to: A. Smirnov (alexander.smirnov-1@nasa.gov)

Received: 22 November 2011 - Published in Atmos. Meas. Tech. Discuss.: 5 December 2011 Revised: 3 February 2012 - Accepted: 6 February 2012 - Published: 17 February 2012

\begin{abstract}
The Maritime Aerosol Network (MAN) has been collecting data over the oceans since November 2006. The MAN archive provides a valuable resource for aerosol studies in maritime environments. In the current paper we investigate correlations between ship-borne aerosol optical depth (AOD) and near-surface wind speed, either measured (onboard or from satellite) or modeled (NCEP). According to our analysis, wind speed influences columnar aerosol optical depth, although the slope of the linear regression between AOD and wind speed is not steep $(\sim 0.004-0.005)$, even for strong winds over $10 \mathrm{~m} \mathrm{~s}^{-1}$. The relationships show significant scatter (correlation coefficients typically in the range $0.3-0.5)$; the majority of this scatter can be explained by the uncertainty on the input data. The various wind speed sources considered yield similar patterns. Results are in good agreement with the majority of previously published relationships between surface wind speed and ship-based or
\end{abstract}

satellite-based AOD measurements. The basic relationships are similar for all the wind speed sources considered; however, the gradient of the relationship varies by around a factor of two depending on the wind data used.

\section{Introduction}

The World Ocean is the largest source of natural aerosol. Accurate estimation of sea-spray aerosol production, evolution and removal processes is important for understanding the Earth's radiation budget, aerosol-cloud interactions, and visibility changes (Latham and Smith, 1990; O'Dowd et al., 1999; Haywood et al., 1999; de Leeuw et al., 2000). The wind speed is the major driver behind the production of natural marine aerosol (Lewis and Schwartz, 2004). The marine aerosol concentration and size distribution are strongly 
a)

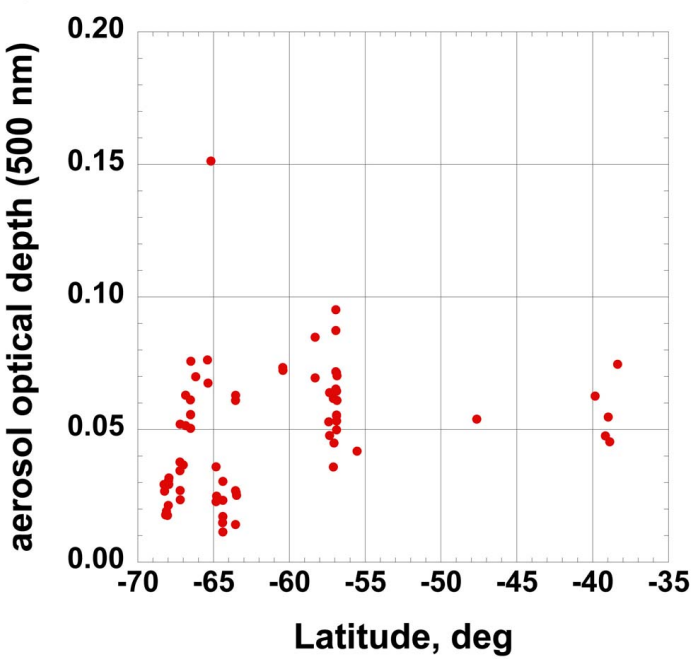

b)

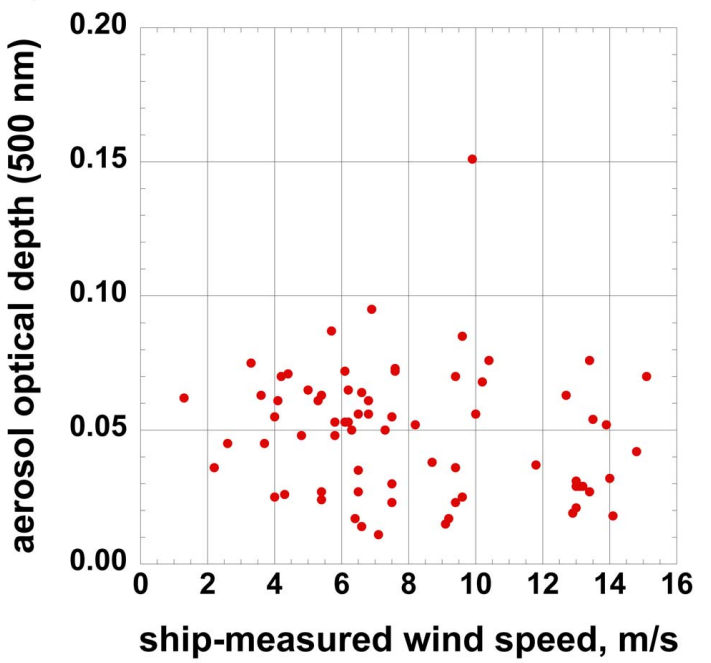

Fig. 1. Latitudinal dependence of AOD series acquired at least $200 \mathrm{~km}$ from the nearest landmass (a), and AOD dependence on ship-based wind speed (b) during the February-April 2008 cruise of the R/V Polarstern.

dependent on wind speed (Blanchard and Woodcock, 1980; Gathman, 1982; Lovett, 1978), however, the dependence of columnar aerosol optical depth (AOD) on wind speed is more difficult to detect and quantify, because of scores of different factors influencing AOD (Smirnov et al., 1995). Establishing correct relationships between AOD and near-surface wind speed will help tune global aerosol transport models (Jaegle et al., 2011; Madry et al., 2011; Fan and Toon, 2011), atmospheric correction in ocean-color studies (Zibordi et al., 2011), validate AODs retrieved from satellite measurements (Kahn et al., 2010; Kleidman et al., 2012), and understand biogeochemical cycles (Meskhidze and Nenes, 2010).

Recently an increased interest in aerosol optical depth over the oceans and its dependence on wind speed manifested itself in a number of publications. Satellite-derived and coast or island acquired AODs have been studied by Mulcahy et al. (2008), Glantz et al. (2009), Lehahn et al. (2010), Huang et al. (2010), O'Dowd et al. (2010), Kiliyanpilakkil and Meskhidze (2011), Grandey et al. (2011), Adames et al. (2011), and Sayer et al. (2012). Power-law and linear relationships between AOD and wind speed were established although sampling issues, uncertainties in retrieval algorithms, and/or influence of the chosen island locations gave an indication that the problem is far from being solved and there is not yet consensus.

Satellite-based measurements are undoubtedly the only tool (at least at present) for global aerosol optical depth coverage. However because of existing satellite retrieval biases (Smirnov et al., 2006, 2011) the ground (ocean)-based truth is needed to correct or constrain them. For example, in the southern latitudes (south of $40^{\circ}$ ) the sunphotometer AODs are low compared with satellite retrievals (Smirnov et al., 2006, 2011). This discrepancy can be explained, at least partly, by uncertainties in foam formation and its latitudinal distribution (Anguelova and Webster, 2006), by a process of quality control that excludes some residual cloud contamination (Zhang and Reid, 2010), by the accuracy of radiative transfer models used (Melin et al., 2010), and by more accurate accounting for surface reflectance effects in satellite retrievals (Sayer et al., 2010).

Therefore it is useful to utilize the available archive of ship-based AOD measurements over the oceans acquired within the framework of Maritime Aerosol Network (Smirnov et al., 2009), and analyze AOD in conjunction with information on near-surface wind speed from various sources: measured onboard, simulated by the National Center for Environmental Prediction (NCEP), and estimated from measurements taken by the Advanced Microwave Scanning Radiometer (AMSR-E) aboard Aqua satellite.

\section{Data sets used in this study}

MAN accumulated more than 2500 days of ship-based AOD measurements over a period of several years (Smirnov et al., 2009, 2011). MAN deploys hand held Microtops II sunphotometers (Morys et al., 2001) and utilizes calibration and data processing procedures traceable to AERONET (Holben et al., 1998, 2001). The estimated uncertainty of the optical depth in each channel does not exceed \pm 0.02 (Knobelspiesse et al., 2004), primarily due to inter-calibration against AERONET reference CIMEL instruments that are accurate to within $\sim 0.01$ in the visible and near-infrared (Eck et al., 1999). Thus MAN provides high-quality AODs with known uncertainty. A public domain web-based archive dedicated 

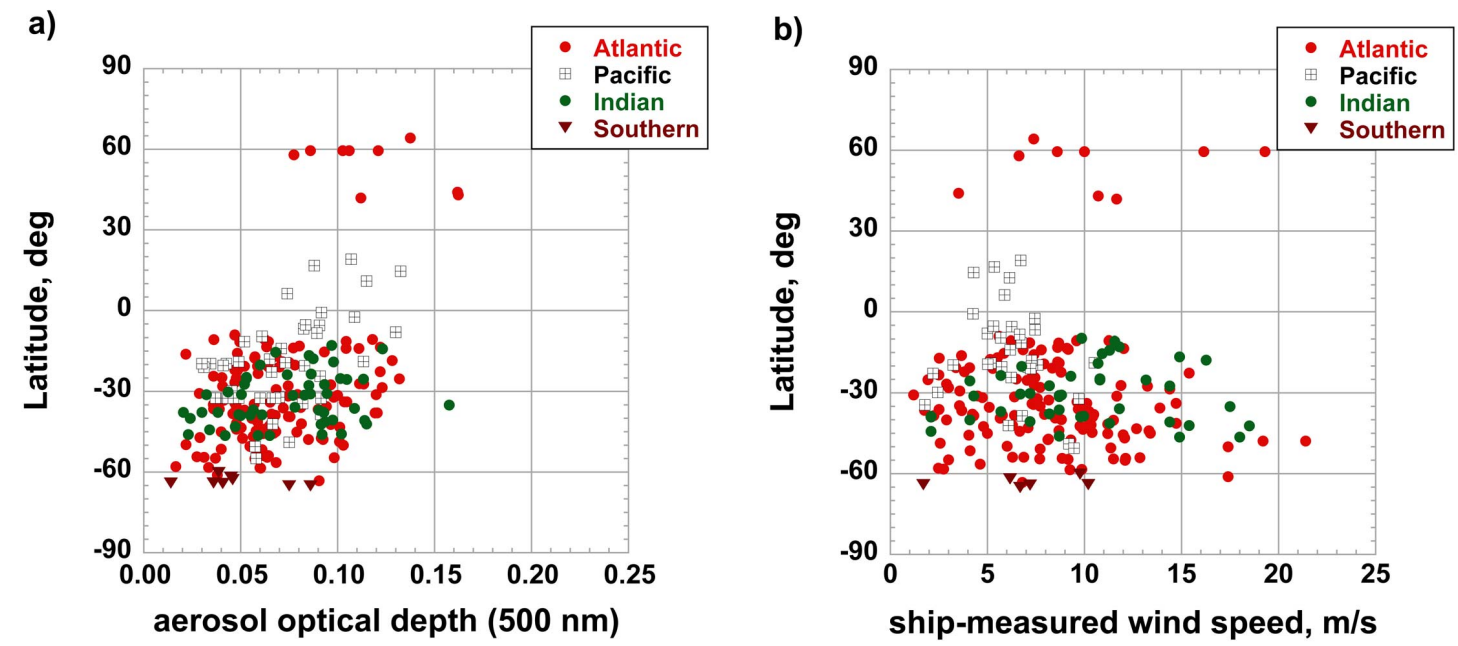

Fig. 2. Latitudinal dependence of AOD daily averages used in this study (a), and latitudinal dependence of corresponding daily averaged ship-based wind speed (b).
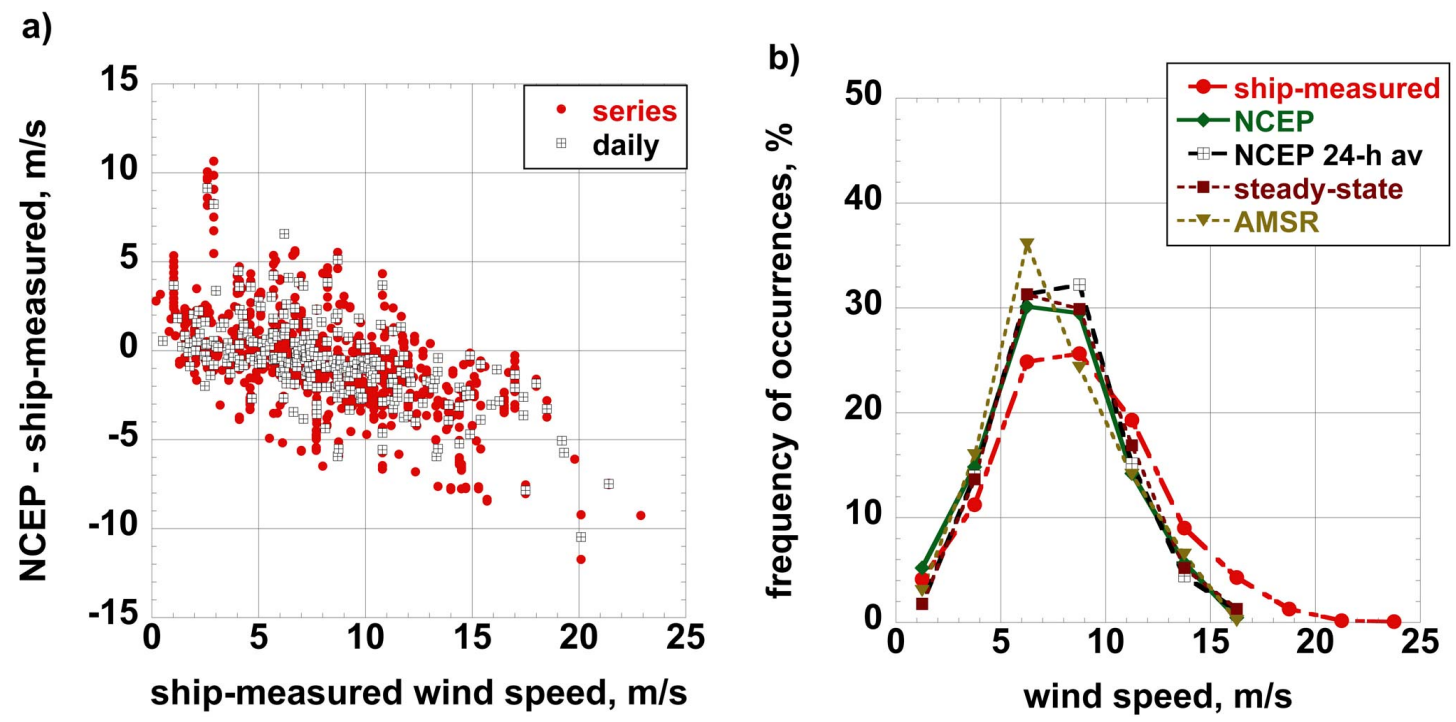

Fig. 3. Differences between NCEP and ship-based wind speed as a function of ship-based wind speed (a) and wind speed frequency of occurrences $(\%)$ for each subset (b).

to the network activity can be found at: http://aeronet.gsfc. nasa.gov/new_web/maritime_aerosol_network.html.

The ship-based meteorological data collected onboard were provided by the cruise PIs. Meteorological measurements were made with the standard equipment at least hourly. Then linear interpolation was applied to match in time sunphotometer measurements.

The National Center for Environmental Prediction (NCEP) wind speed data used was $1^{\circ}$ by $1^{\circ}$ horizontal resolution output every $6 \mathrm{~h}$ (Derber et al., 1991). In our analysis, for each measured AOD the NCEP near-surface $(10 \mathrm{~m})$ wind speed data points were linearly interpolated in space and time to provide the "instantaneous" wind speed. Repeating this procedure backwards in time, we additionally computed wind speeds averaged over the $24 \mathrm{~h}$ period prior to each AOD measurement.

The Advanced Microwave Scanning Radiometer-Earth Observing System (AMSR-E) instrument on the NASA Earth Observing System (EOS) Aqua satellite provides nearsurface wind speed (Wentz and Meissner, 2007). These data are provided at a spatial resolution of $25 \mathrm{~km}$, separately for daytime and nighttime overpasses. In this study, the data point which the MAN measurement lies within was used. Because the AMSR-E sampling is spatially incomplete, some MAN data lacked a corresponding AMSR-E wind speed retrieval. 

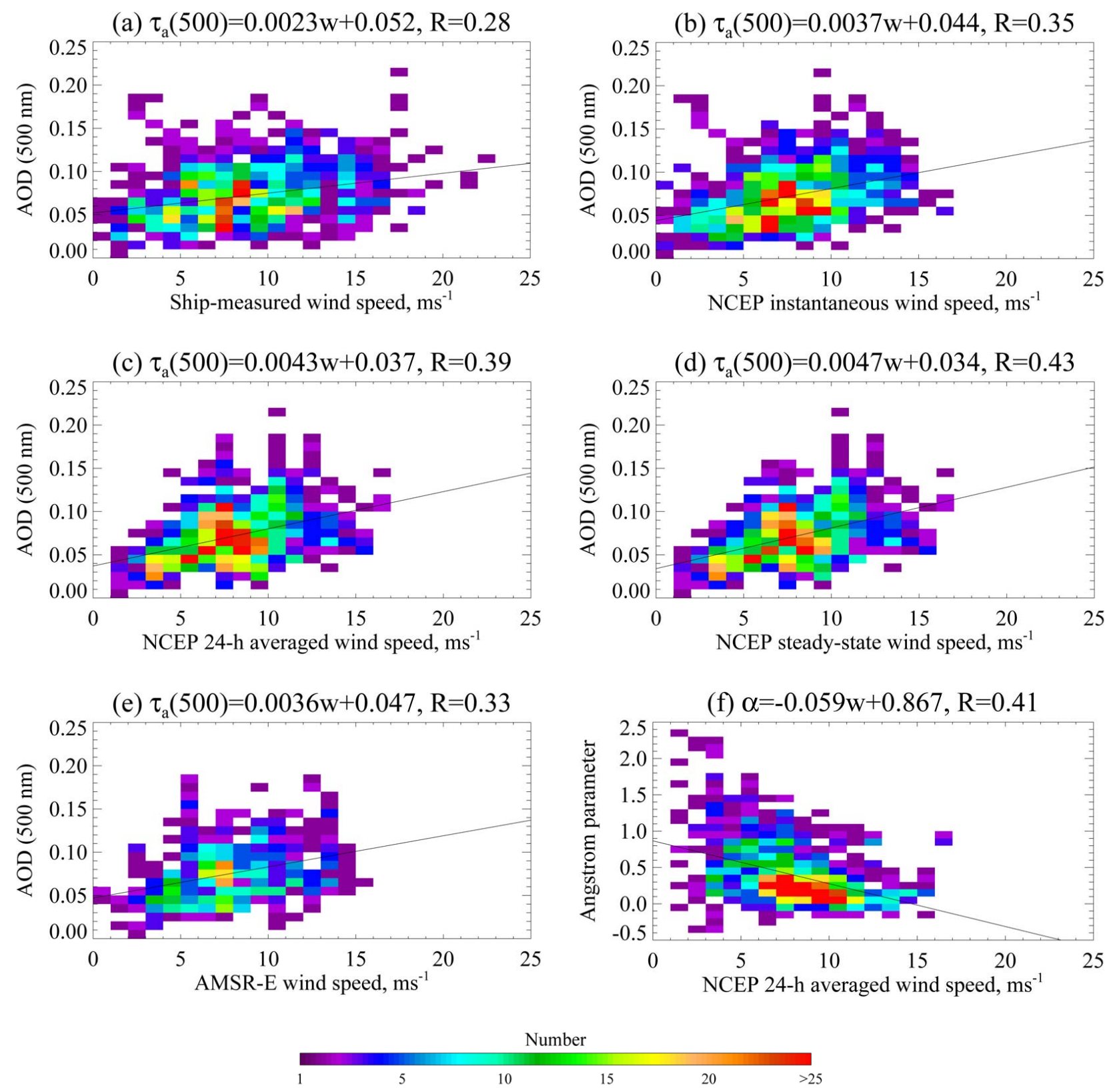

Fig. 4. Scatter density histograms of AOD at $500 \mathrm{~nm}$ (series) (a-e) and Angstrom parameter (f) versus the surface wind speed.

The influence of wind speed on AOD in the whole atmospheric column is a very difficult problem. A link between optical turbidity and particle generation by wind is not easy to detect, since it can be masked by the background aerosol (of continental origin in coastal areas, for example). Accordingly, surface generation effects can be clearly noticed only when measurements are taken in a reasonably transparent atmosphere. Ideally a relationship between spectral aerosol optical depth and wind speed needs to be ascertained in the same air mass in order to minimize the influence of other meteorological parameters on optical properties, or when all meteorological parameters are simply the same over the range of wind speeds considered. Discriminating between air masses permits a more rigorous analysis of the link between wind speed and optical depth (Smirnov et al., 1995). The correlations between AOD and wind speed in maritime tropical air masses were found to be significantly larger than those obtained in a study of the same Pacific Ocean data (Villevalde et al., 1994), where no air mass discrimination was made. This means that the correlation coefficient increased when the data were characterized by more uniform atmospheric conditions. 


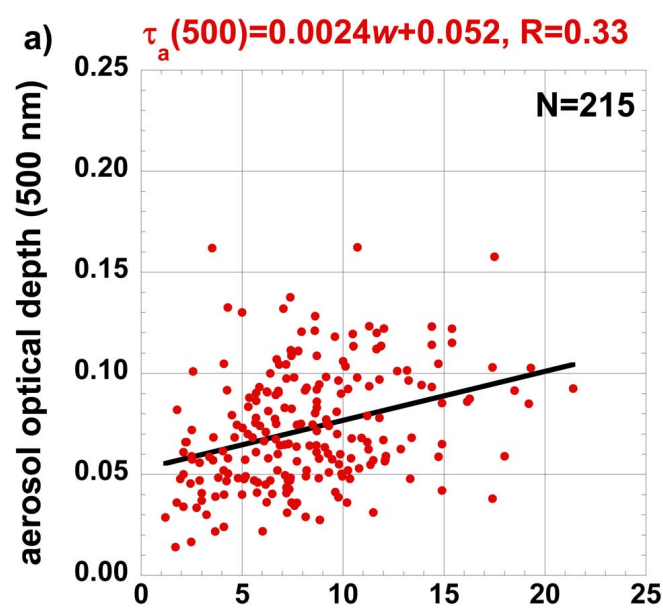

ship-measured wind speed, $\mathrm{m} / \mathrm{s}$
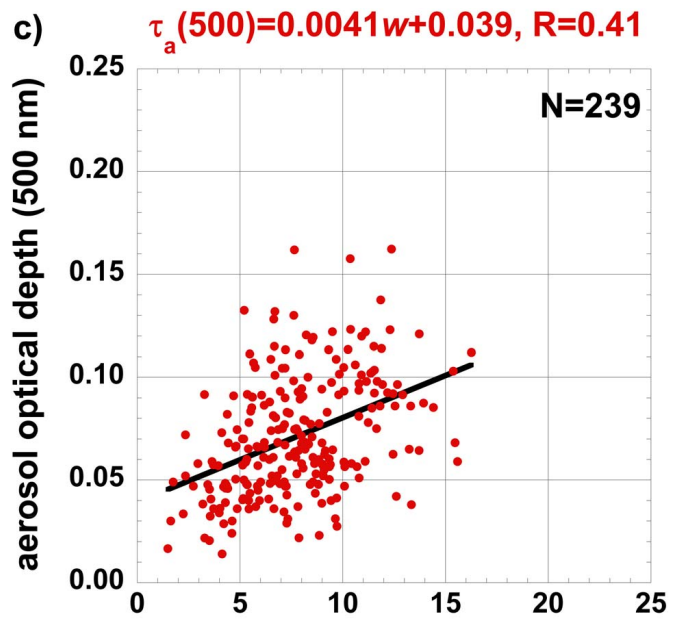

NCEP 24-h averaged wind speed, $\mathrm{m} / \mathrm{s}$

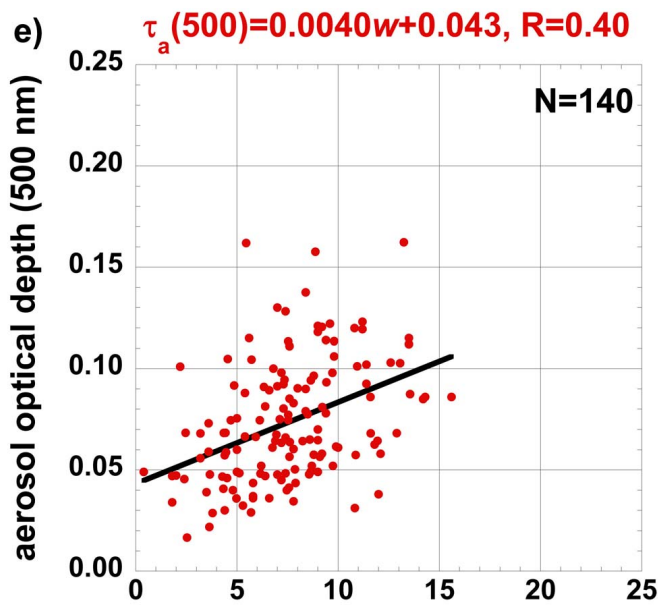

AMSR-E wind speed, $\mathrm{m} / \mathrm{s}$

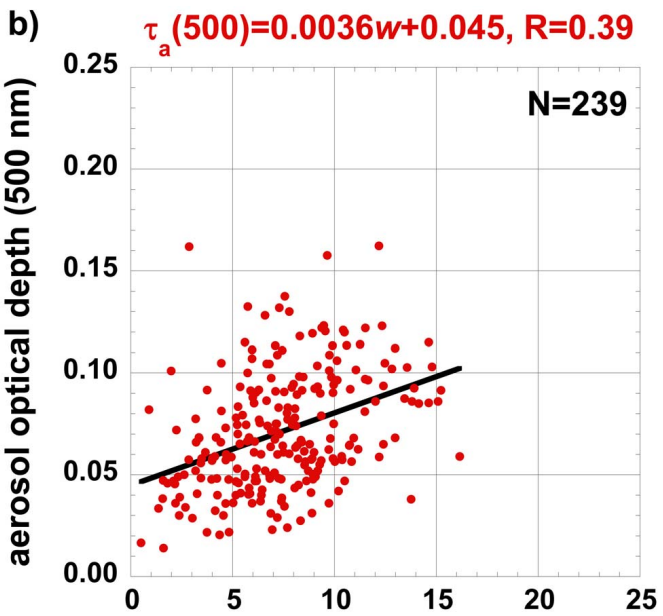

NCEP instantaneous wind speed, $\mathrm{m} / \mathrm{s}$
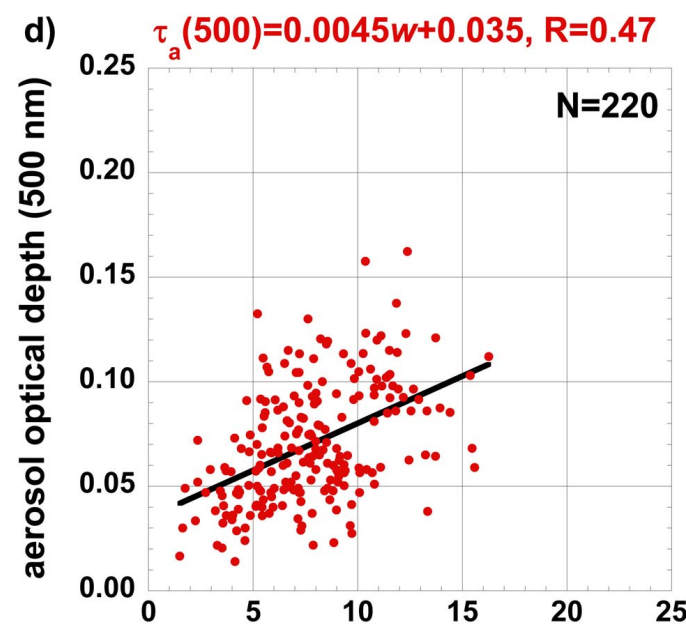

NCEP steady-state wind speed, $\mathrm{m} / \mathrm{s}$

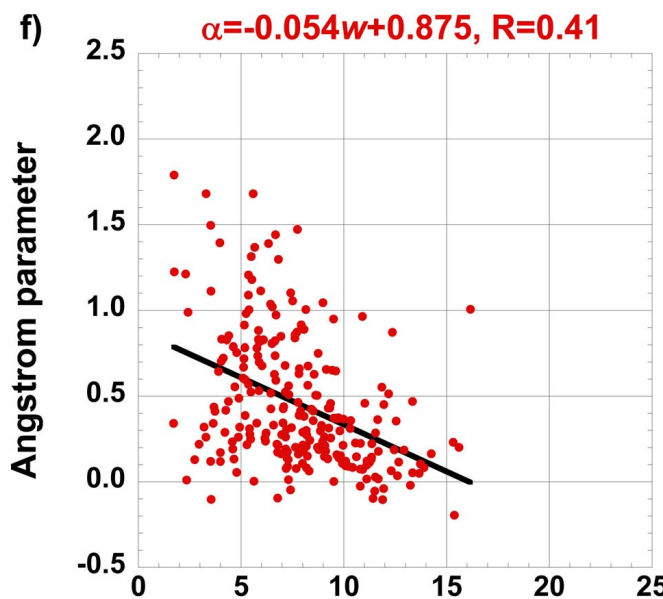

NCEP 24-h averaged wind speed, $\mathrm{m} / \mathrm{s}$

Fig. 5. Scattergrams of daily averaged AOD at $500 \mathrm{~nm}(\mathbf{a}-\mathbf{e})$ and Angstrom parameter (f) versus the surface wind speed. 
Table 1. List of cruises, cruise areas, and number of measurement days used in our analysis.

\begin{tabular}{|c|c|c|c|c|}
\hline Cruise name & Cruise area & Time period & $N$ of days & PI \\
\hline R/V Akademik Fedorov 2005-2006 & South AO & Dec 2005 & 1 & B. Holben and S. Sakerin \\
\hline R/V Akademik Fedorov 2006-2007 & South AO & Dec 2006 & 5 & B. Holben and S. Sakerin \\
\hline R/V Akademik Fedorov 2007-2008 & South AO, South IO & Dec 2007-Apr 2008 & 17 & B. Holben and S. Sakerin \\
\hline R/V Akademik Fedorov 2008-2009 & South AO & Dec 2008 & 1 & B. Holben and S. Sakerin \\
\hline R/V Akademik Fedorov 2009-2010 & Southern O, South AO & Dec 2009; Feb 2010 & 2 & B. Holben and S. Sakerin \\
\hline R/V Akademik Ioffe 2009 & South AO & Nov 2009 & 9 & B. Holben and S. Gulev \\
\hline R/V Akademik Ioffe 2010 & North AO & Sep 2010 & 4 & B. Holben and S. Gulev \\
\hline R/V Akademik Sergey Vavilov & South AO & Nov-Dec 2004 & 17 & B. Holben and S. Sakerin \\
\hline RRS James Clark Ross 2008 & South AO & Oct-Nov 2008 & 8 & B. Holben and T. Smyth \\
\hline RRS James Cook 2009 & South AO & Nov 2009 & 10 & B. Holben and T. Smyth \\
\hline RRS James Cook 2010 & South AO & Nov 2010 & 6 & B. Holben and T. Smyth \\
\hline R/V Knorr 2008 & North AO & Mar-Apr 2008 & 5 & P. Quinn \\
\hline R/V Marion Dufresne 2007 & South IO & Nov-Dec 2007 & 14 & B. Holben and J. Sciare \\
\hline R/V Marion Dufresne 2008 & South IO & Nov-Dec 2008 & 11 & B. Holben and R. Losno \\
\hline R/V Marion Dufresne 2009 & South IO & Nov-Dec 2009 & 8 & Y. Courcoux \\
\hline R/V Marion Dufresne 2010 & South IO & Jan, Aug-Sep 2010 & 18 & Y. Courcoux \\
\hline R/V Melville 2009-2010 & South PO & Jan-Feb 2010 & 8 & B. Holben and N. Nelson \\
\hline R/V Polarstern 2008 & Southern O, South AO & Feb-Apr 2008 & 16 & B. Holben and P. Croot \\
\hline R/V Polarstern 2008 & South AO & Apr-May 2008 & 9 & B. Holben and A. Macke \\
\hline R/V Polarstern 2009 & South AO & Apr-May, Nov 2009 & 27 & B. Holben and A. Macke \\
\hline R/V Polarstern 2010 & South AO & Apr 2010 & 10 & B. Holben and S. Kinne \\
\hline R/V Ronald H. Brown 2007-2008 & North and South PO & Dec 2007-Feb 2008 & 26 & B. Holben and N. Nelson \\
\hline R/V Ronald H. Brown 2008 & South PO & Oct-Nov 2008 & 10 & P. Quinn \\
\hline M/V SA Agulhas & Southern O, South AO & Dec 2007-Jan 2008 & 13 & B. Holben and S. Piketh \\
\hline
\end{tabular}

In other words, the relationship between AOD and wind speed depends on many factors we simply do not know or cannot fully account for (at least empirically). A good example is presented in Fig. 1a and b. The R/V Polarstern cruise considered took place in the winter of 2008 in the South Atlantic and Southern Ocean (Dr. Peter Croot was a PI for AOD measurements). Figure 1a shows the latitudinal dependence of AOD series (a series can have one or more measurements points, typically five or more, made with a gap of under 2 min; see Smirnov et al., 2009 for details) acquired at least $200 \mathrm{~km}$ from the nearest landmass, and Fig. $1 \mathrm{~b}$ presents a dependence on ship-based wind speed. It is clear that there is no obvious relationship between AOD and wind speed for the subset considered. AODs are quite low while the wind speed ranges from 3 to $14 \mathrm{~m} \mathrm{~s}^{-1}$. Additional consideration of the subset acquired within $39^{\circ}-65^{\circ} \mathrm{S}$ did not produce any correlation either.

Therefore in our analysis we decided to deploy the following strategy. Because all factors influencing the dependence of AOD on wind speed cannot be accounted for, we simply considered only data presumably not influenced by urban/industrial continental sources, dust outbreaks, biomass burning, or glaciers and pack ice. In the Northern Atlantic we limited the area to the latitudinal belt between $40^{\circ}-60^{\circ} \mathrm{N}$; in the Southern Atlantic we considered data acquired to the South of $10^{\circ} \mathrm{S}$; in the Indian Ocean data set included only

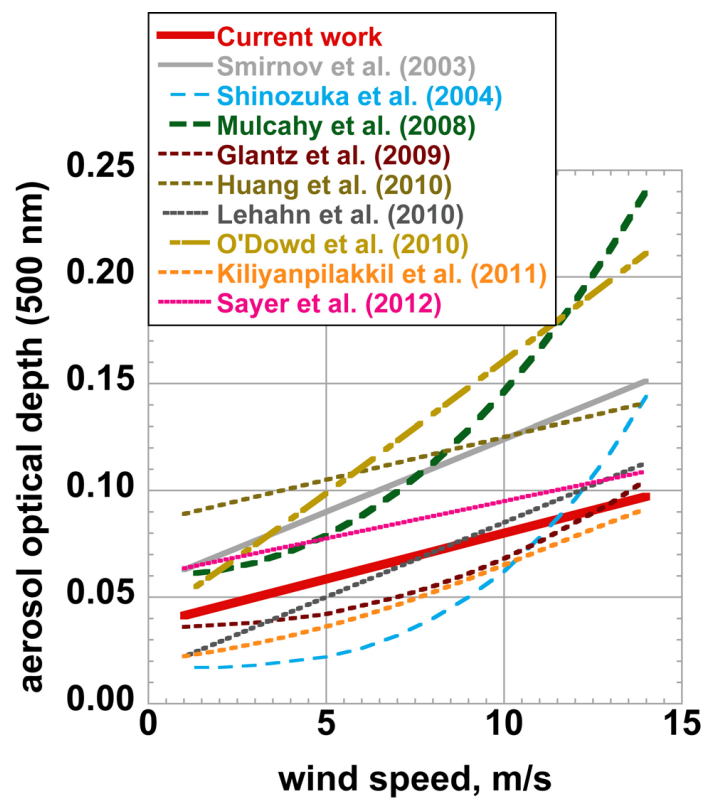

Fig. 6. Maritime aerosol optical depth as a function of wind speed. 

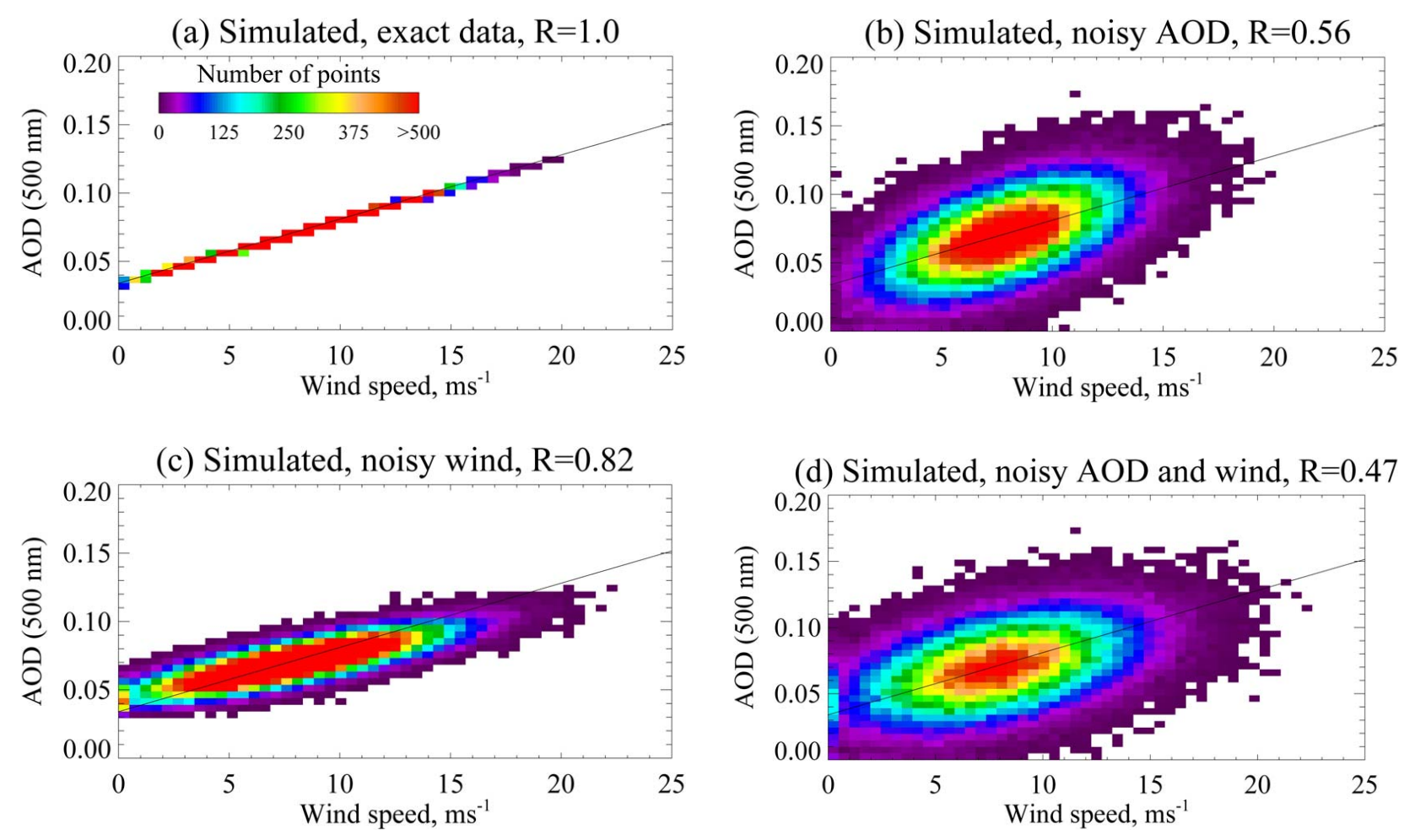

Fig. 7. Scatter density histogram between simulated noise-free wind speed and noise-free AOD (a), noisy AOD and noise-free wind speed (b), noisy wind speed and noise-free AOD (c) and noisy wind speeds and noisy AOD at $500 \mathrm{~nm}(\mathbf{d})$. Points were generated assuming the steadystate relationship in Table $3, \tau_{\mathrm{a}}(500 \mathrm{~nm})=0.0047 \times w+0.034$ (shown in black), and then adding Gaussian noise of amplitude $2 \mathrm{~m} \mathrm{~s}^{-1}$ to the winds and 0.02 to the AOD.

cruises South of $9^{\circ} \mathrm{S}$. An additional restriction imposed on the data set was exclusion of points taken closer than two degrees from the nearest landmass. Among the selected cruises, we excluded one (presented in Fig. 1), which showed no relationship between AOD and wind speed. For any other individual cruise considered, the slope of the AOD scatterplot versus wind speed was found to be at least $0.002 \mathrm{~s} \mathrm{~m}^{-1}$. This "cherry-picking" is justified by the ultimate goal of finding the most robust possible dependence of AOD on wind speed over the oceans. Table 1 presents final dataset used for our analysis. Overall we considered 239 measurement days. Figure 2a shows AOD daily averages as a function of latitude, and Fig. $2 b$ presents corresponding daily averages of the ship-based wind speed.

The NCEP wind speed data were interpolated in space and time to match the AOD measurement series. In addition to the "instantaneous" wind speeds (wind speeds at the times matching the AOD series), we used wind speeds averaged over the $24 \mathrm{~h}$ prior to each AOD measurement, and also the subset of "steady-state" wind speeds (defined similar to Madry et al., 2011, i.e., standard deviation for the daily averaged wind speed should not exceed $2 \mathrm{~m} \mathrm{~s}^{-1}$ for wind speeds less than $10 \mathrm{~m} \mathrm{~s}^{-1}$, or $3 \mathrm{~m} \mathrm{~s}^{-1}$ for wind speeds greater than $10 \mathrm{~m} \mathrm{~s}^{-1}$ ). NCEP data were compared with the ship-based meteorological information for cruises considered, and this is presented in Fig. 3a. The relative negative offset of NCEP is evident, although it is not critical for our study. About $66 \%$ of the differences are within $2 \mathrm{~m} \mathrm{~s}^{-1}$. The "series" and "daily" wind speed differences are comparable. Figure $3 \mathrm{~b}$ shows histograms of wind speeds used in our further analysis. High winds (greater than $10 \mathrm{~m} \mathrm{~s}^{-1}$ ) account for over $20 \%$ in each subset considered.

\section{Results}

Figures 4 and 5, and Table 2, illustrate regressions between aerosol optical depth, Angstrom parameter (negative of the logarithmic gradient of AOD with wavelength, over the visible spectrum) and wind speed. More than 1100 series from 239 days of aerosol optical depth measurements contributed to the statistics presented. Overall we can conclude that the relationship between AOD and wind speed is linear, but correlations are not strong (non-linear relationships were considered, but did not result in stronger correlations). Even for the case of "steady-state" winds, correlations coefficients do not increase significantly. These values, although not high, are statistically significant at a $99 \%$ confidence level. Results obtained for the "daily" and "series" datasets are comparable. Averaging AOD over a day removes some noise, 
Table 2. Regression statistics of spectral optical parameters versus wind speed.

\begin{tabular}{|c|c|c|c|c|c|c|c|c|}
\hline Relationship & Data source & $a$ & $b$ & $R^{*}$ & Data source & $a$ & $b$ & $R^{*}$ \\
\hline$\tau_{\mathrm{a}}(440 \mathrm{~nm})=a \times w_{(\mathrm{ship})}+b$ & series & 0.0020 & 0.062 & 0.23 & daily average & 0.0022 & 0.061 & 0.29 \\
\hline$\tau_{\mathrm{a}}(500 \mathrm{~nm})=a \times w_{(\text {ship })}+b$ & & 0.0023 & 0.052 & 0.28 & & 0.0024 & 0.052 & 0.33 \\
\hline$\tau_{\mathrm{a}}(675 \mathrm{~nm})=a \times w_{(\mathrm{ship})}+b$ & & 0.0029 & 0.038 & 0.38 & & 0.0031 & 0.035 & 0.47 \\
\hline$\tau_{\mathrm{a}}(870 \mathrm{~nm})=a \times w_{(\text {ship })}+b$ & & 0.0027 & 0.039 & 0.37 & & 0.0030 & 0.037 & 0.46 \\
\hline$\tau_{\mathrm{a}}(440 \mathrm{~nm})=a \times w_{(\mathrm{NCEP})}+b$ & series & 0.0034 & 0.052 & 0.31 & daily average & 0.0035 & 0.052 & 0.35 \\
\hline$\tau_{\mathrm{a}}(500 \mathrm{~nm})=a \times w_{(\mathrm{NCEP})}+b$ & & 0.0037 & 0.044 & 0.35 & & 0.0036 & 0.045 & 0.39 \\
\hline$\tau_{\mathrm{a}}(675 \mathrm{~nm})=a \times w_{(\mathrm{NCEP})}+b$ & & 0.0043 & 0.029 & 0.44 & & 0.0043 & 0.028 & 0.50 \\
\hline$\tau_{\mathrm{a}}(870 \mathrm{~nm})=a \times w_{(\mathrm{NCEP})}+b$ & & 0.0042 & 0.030 & 0.45 & & 0.0043 & 0.028 & 0.52 \\
\hline$\tau_{\mathrm{a}}(440 \mathrm{~nm})=a \times w_{(<24 \mathrm{~h}>, \mathrm{NCEP})}+b$ & series & 0.0042 & 0.044 & 0.35 & daily average & 0.0040 & 0.047 & 0.38 \\
\hline$\tau_{\mathrm{a}}(500 \mathrm{~nm})=a \times w_{(<24 \mathrm{~h}>, \mathrm{NCEP})}+b$ & & 0.0043 & 0.037 & 0.39 & & 0.0041 & 0.039 & 0.41 \\
\hline$\tau_{\mathrm{a}}(675 \mathrm{~nm})=a \times w_{(<24 \mathrm{~h}>, \mathrm{NCEP})}+b$ & & 0.0049 & 0.023 & 0.47 & & 0.0048 & 0.022 & 0.53 \\
\hline$\tau_{\mathrm{a}}(870 \mathrm{~nm})=a \times w_{(<24 \mathrm{~h}>, \mathrm{NCEP})}+b$ & & 0.0049 & 0.023 & 0.48 & & 0.0049 & 0.022 & 0.55 \\
\hline$\tau_{\mathrm{a}}(440 \mathrm{~nm})=a \times w_{(\text {steady }- \text { state }, \mathrm{NCEP})}+b$ & series & 0.0045 & 0041 & 0.40 & daily average & 0.0044 & 0.042 & 0.44 \\
\hline$\tau_{\mathrm{a}}(500 \mathrm{~nm})=a \times w_{(\text {steady }- \text { state }, \mathrm{NCEP})}+b$ & & 0.0047 & 0.034 & 0.43 & & 0.0045 & 0.035 & 0.47 \\
\hline$\tau_{\mathrm{a}}(675 \mathrm{~nm})=a \times w_{(\text {steady }- \text { state }, \mathrm{NCEP})}+b$ & & 0.0052 & 0.021 & 0.50 & & 0.0051 & 0.019 & 0.56 \\
\hline$\tau_{\mathrm{a}}(870 \mathrm{~nm})=a \times w_{(\text {steady }- \text { state }, \mathrm{NCEP})}+b$ & & 0.0051 & 0.021 & 0.51 & & 0.0052 & 0.019 & 0.58 \\
\hline$\tau_{\mathrm{a}}(440 \mathrm{~nm})=a \times w_{(\mathrm{AMSR})}+b$ & series & 0.0033 & 0.056 & 0.28 & daily average & 0.0040 & 0.050 & 0.38 \\
\hline$\tau_{\mathrm{a}}(500 \mathrm{~nm})=a \times w_{(\mathrm{AMSR})}+b$ & & 0.0036 & 0.047 & 0.33 & & 0.0040 & 0.043 & 0.40 \\
\hline$\tau_{\mathrm{a}}(675 \mathrm{~nm})=a \times w_{(\mathrm{AMSR})}+b$ & & 0.0041 & 0.034 & 0.40 & & 0.0046 & 0.028 & 0.50 \\
\hline$\tau_{\mathrm{a}}(870 \mathrm{~nm})=a \times w_{(\mathrm{AMSR})}+b$ & & 0.0036 & 0.038 & 0.37 & & 0.0045 & 0.029 & 0.50 \\
\hline$\alpha=a \times w_{(\text {ship })}+b$ & series & -0.036 & 0.706 & 0.35 & daily average & -0.035 & 0.732 & 0.36 \\
\hline$\alpha=a \times w_{(\mathrm{NCEP})}+b$ & & -0.051 & 0.789 & 0.39 & & -0.048 & 0.813 & 0.38 \\
\hline$\alpha=a \times w_{(<24 \mathrm{~h}>, \mathrm{NCEP})}+b$ & & -0.059 & 0.867 & 0.41 & & -0.054 & 0.875 & 0.41 \\
\hline$\alpha=a \times w_{(\text {steady }- \text { state }, \mathrm{NCEP})}+b$ & & -0.059 & 0.863 & 0.42 & & -0.053 & 0.864 & 0.40 \\
\hline$\alpha=a \times w_{(\mathrm{AMSR})}+b$ & & -0.038 & 0.648 & 0.31 & & -0.042 & 0.747 & 0.34 \\
\hline
\end{tabular}

${ }^{*} R-$ is a linear correlation coefficient.

associated in part with uncertainties in the AOD and wind speed, and in part with natural variability, and makes correlation coefficients slightly higher (by less than 0.1). Various wind data sources and wind speed subsets yielded very similar results. As expected Angstrom parameter decreases with wind speed. An influx of large particles is responsible, at least in part, for this anticorrelation.

The slope of the linear regression of AOD versus wind speed lies in the range $0.002-0.005$ for the various wavelengths, cruises, and wind datasets considered. As expected (because the wind speed's history is important) the dataset that uses wind speed averaged within previous $24 \mathrm{~h}$ period and "steady-state" wind dataset yielded higher slopes. Table 3 presents regression statistics compiled from various publications. Our results are consistent with the majority of previously reported results for ship-based and islandbased measurements, although being different from Mulcahy et al. (2008). We would like to note that additional consideration of stricter "steady-state" wind conditions (with standard deviation less than $1 \mathrm{~m} \mathrm{~s}^{-1}$ within previous $24 \mathrm{~h}$ ) did not change the slope at $500 \mathrm{~nm}$, but slightly increased it to 0.0058 at $870 \mathrm{~nm}$. Some of the satellite-derived AODs yielded steeper slopes, although we believe these to be an artifact of the satellite-derived AOD overestimation (Smirnov et al., 2006, 2011).
In Fig. 6 the relationship between AOD and NCEP wind averaged within previous $24 \mathrm{~h}$ ("current study") is compared to other studies. The diversity between different relationships established in the literature is evident. However, over the range $0-10 \mathrm{~m} \mathrm{~s}^{-1}$, the typical change in AOD is similar in most parameterizations $(\sim 0.04$ at $500 \mathrm{~nm})$, and consistent with the ship-borne measurements from this study. The main differences between studies are linked to the baseline AOD for low-wind conditions, and some nonlinearities at high wind speeds. In the former case, this may be partially explained by local aerosol sources or satellite retrieval biases, specific to each individual study's dataset. In the latter case, this may often be linked to a paucity of data for high wind speeds, such that the determination of the form of the relationship is less well-defined (although as mentioned previously, over $20 \%$ of the MAN AODs are for wind speeds of $10 \mathrm{~m} \mathrm{~s}^{-1}$ or greater). Further, data from coastal sites may be more strongly affected by enhanced foam from breaking waves at high wind speeds, and satellite biases (Sayer et al., 2010; Smirnov et al., 2006, 2011) may be more extreme in such cases. These effects would not be expected to influence the MAN AODs in the same way.

To investigate the extent to which uncertainties in the AOD and wind speed contribute to the low correlations, a numerical simulation was performed, based on the "steady-state" 
Table 3. Regression statistics of aerosol optical depth versus wind speed.

\begin{tabular}{|c|c|c|c|c|c|c|}
\hline Reference & $\begin{array}{l}\text { AOD } \\
\text { source }\end{array}$ & $\begin{array}{l}\text { Wind } \\
\text { source }\end{array}$ & Region & Relationship & $a$ & $b$ \\
\hline Current paper & SP & $\begin{array}{l}\text { Ground } \\
\text { Model } \\
\text { Model } \\
\text { Model } \\
\text { Satellite }\end{array}$ & Global & $\begin{array}{l}\tau_{\mathrm{a}}(500 \mathrm{~nm})=a \times w_{(\text {ship })}+b \\
\tau_{\mathrm{a}}(500 \mathrm{~nm})=a \times w_{(\text {instantaneous }, \mathrm{NCEP})}+b \\
\tau_{\mathrm{a}}(500 \mathrm{~nm})=a \times w_{(<24 \mathrm{~h}>, \mathrm{NCEP})}+b \\
\tau_{\mathrm{a}}(500 \mathrm{~nm})=a \times w_{(\text {steady }- \text { state }, \mathrm{NCEP})}+b \\
\tau_{\mathrm{a}}(500 \mathrm{~nm})=a \times w_{(\text {AMSR })}+b\end{array}$ & $\begin{array}{l}0.0023 \\
0.0037 \\
0.0043 \\
0.0047 \\
0.0036\end{array}$ & $\begin{array}{l}0.052 \\
0.044 \\
0.037 \\
0.034 \\
0.047\end{array}$ \\
\hline Platt and Patterson (1986) & SP & Ground & Cape Grim & $\tau_{\mathrm{a}}(500 \mathrm{~nm})=a \times w+b$ & 0.0028 & 0.046 \\
\hline Villevalde et al. (1994) & SP & Ground & Pacific & $\tau_{\mathrm{a}}(500 \mathrm{~nm})=a \times w+b$ & 0.0033 & 0.101 \\
\hline Smirnov et al. (1995) & SP & Ground & Pacific & $\tau_{\mathrm{a}}(500 \mathrm{~nm})=a \times w+b$ & 0.0036 & 0.123 \\
\hline Wilson and Forgan (2002) & SP & Ground & Cape Grim & $\tau_{\mathrm{a}}(500 \mathrm{~nm})=a \times w+b$ & 0.0035 & -0.006 \\
\hline Smirnov et al. (2003) & SP & Ground & Midway & $\tau_{\mathrm{a}}(500 \mathrm{~nm})=a \times w_{<24 \mathrm{~h}>}+b$ & 0.0068 & 0.056 \\
\hline Shinozuka et al. (2004) & SP & Ground & Pacific & $\tau_{\mathrm{a}}(500 \mathrm{~nm})=b+4.9 \times 10^{-5} w^{3}-3.7 \times 10^{-5} w^{2}$ & & 0.017 \\
\hline Muclahy et al. (2008) & SP & Ground & Mace Head & $\tau_{\mathrm{a}}(500 \mathrm{~nm})=b+5.5 \times 10^{-4} w^{2.195}$ & & 0.060 \\
\hline Lehahn et al. (2010) & SP & Satellite & Global, island sites & $\tau_{\mathrm{ac}}(500 \mathrm{~nm})=a \times w+b$ & 0.0070 & 0.015 \\
\hline Adames et al. (2011) & SP & Ground & Atlantic & $\tau_{\mathrm{a}}(500 \mathrm{~nm})=a \times w+b$ & 0.0066 & 0.027 \\
\hline Sayer et al. (2012) & SP & Model & Global, island sites & $\tau_{\mathrm{a}}(500 \mathrm{~nm})=a \times w+b$ & 0.0031 & 0.070 \\
\hline Glantz et al. (2009) & SeaWIFS & Model & Pacific & $\tau_{\mathrm{a}}(500 \mathrm{~nm})=b+0.00016 \times w^{2.3}$ & & 0.036 \\
\hline Huang et al. (2010) & AATSR & Model & Global & $\tau_{\mathrm{a}}(550 \mathrm{~nm})=a \times w+b$ & 0.004 & 0.085 \\
\hline Lehahn et al. (2010) & MODIS & Satellite & Global & $\tau_{\mathrm{a}}(500 \mathrm{~nm})=a \times(w-4)+b$ & 0.013 & 0.080 \\
\hline O’Dowd et al. (2010) & MODIS & Satellite & $\begin{array}{l}\text { Pacific } \\
\text { Indian }\end{array}$ & $\begin{array}{l}\tau_{\mathrm{a}}(550 \mathrm{~nm})=b+0.00022 \times w^{2.47} \\
\tau_{\mathrm{a}}(550 \mathrm{~nm})=b+0.033 \times w^{0.72} \\
\tau_{\mathrm{a}}(550 \mathrm{~nm})=b+0.0097 \times w^{1.09} \\
\tau_{\mathrm{a}}(550 \mathrm{~nm})=b+0.011 \times w^{1.04}\end{array}$ & & $\begin{array}{c}0.114 \\
-0.004 \\
0.042 \\
0.040\end{array}$ \\
\hline Kiliyanpilakkil and Meskhidze (2011) & CALIPSO & Satellite & Global & $\tau_{\mathrm{a}}(532 \mathrm{~nm})=0.15 /\left(1+6.7 \times e^{-0.17^{*} w}\right)$ & & \\
\hline Grandley et al. (2011) & MODIS & Model & $\begin{array}{l}\text { N Atlantic } \\
\text { S Atlantic } \\
\text { N Atlantic } \\
\text { S Atlantic }\end{array}$ & $\begin{array}{l}\tau_{\mathrm{a}}(550 \mathrm{~nm})=a \times w+b \\
\tau_{\mathrm{a}}(550 \mathrm{~nm})=a \times w+b \\
\tau_{\mathrm{a}}(550 \mathrm{~nm})=a \times w+b \\
\tau_{\mathrm{a}}(550 \mathrm{~nm})=a \times w+b\end{array}$ & $\begin{array}{l}0.0097 \\
0.0111 \\
0.0089 \\
0.0034\end{array}$ & $\begin{array}{l}0.050 \\
0.041 \\
0.099 \\
0.081\end{array}$ \\
\hline
\end{tabular}

relationship in Table $3, \tau_{\mathrm{a}}(500 \mathrm{~nm})=0.0047 \times w+0.034$. First, a 50000 -member Gaussian distribution of wind speeds with mean $7.93 \mathrm{~m} \mathrm{~s}^{-1}$ and standard deviation $2.96 \mathrm{~m} \mathrm{~s}^{-1}$ (corresponding to the "steady-state" wind distribution in Fig. 3), with any resulting negative wind speeds removed, was generated. The sample size gives statistics robust to two significant figures. This was then used to calculate the AOD, assuming the aforementioned wind speed/AOD relationship was a perfect predictor.

Next, the wind and AOD distributions were perturbed by adding Gaussian noise (zero mean in both cases, standard deviation $2 \mathrm{~m} \mathrm{~s}^{-1}$ for wind speed, and 0.02 for AOD). These uncertainties are reasonably representative of the uncertainty in the input data (e.g., Knobelspiesse et al., 2004, Wallcraft et al., 2009; Sayer et al., 2012). Perturbed negative wind speeds or AODs were then set to zero, as would likely be used as the minimum value to report in such an AOD or wind dataset.

The resulting distributions of data are shown in Fig. 7. Correlating the noisy wind speeds with the "true" simulated AODs give $R=0.82$ (Fig. 7c); correlating true wind speeds with noisy AODs gives $R=0.56$ (Fig. 7b); and correlating noisy wind speeds with noisy AODs gives $R=0.47$ (Fig. 7d).
This last number is similar to the correlations observed in this study, suggesting the principle factor decreasing correlation from unity for the MAN and wind data studied here are uncertainties in the input data (rather than other meteorological effects), and that the noise on the AOD is more critical for this purpose. Halving the magnitude of the Gaussian noise used for the perturbations increases this last correlation to 0.76 , indicating the effect of noise on the correlations could be much reduced with more precise input data.

Performing a linear least-squares fit to the perturbed noisy data gives the relationship $\tau_{\mathrm{a}}(500 \mathrm{~nm})=0.0031 \times w+0.047$, i.e., an increase of the intercept and suppression of the gradient as compared to the true underlying relationship. This result is consistent with the observation from this study that with increasing levels of temporal averaging to decrease noise (instantaneous to daily or steady-state NCEP data), gradients become stronger and intercepts smaller, and suggests that use of only instantaneous data for such analyses will result in an overestimate of the baseline maritime AOD, and underestimate of the response to changes in the wind speed. 


\section{Conclusions}

Our analysis of the Maritime Aerosol Network data showed a linear relationship between aerosol optical depth over the oceans and wind speed for a wind speed range $0-15 \mathrm{~m} \mathrm{~s}^{-1}$. There is no indication of a non-linear power-law or exponential relationship between those quantities for any of the wind datasets (ship-based, NCEP, satellite-based) considered. However, the gradient of the relationship varies by around a factor of two depending on the wind data used. This highlights that the derivation of such relationships is sensitive to not only the AOD data source, but also the wind data source, which may explain some of the variation shown within the literature.

Various wind speed subsets, instantaneous and daily averaged AODs yielded similar regression statistics which proves the robustness of our conclusions. It is noteworthy that, unlike in Smirnov et al. (2003) the wind speed range considered here was significantly wider - up to $15 \mathrm{~m} \mathrm{~s}^{-1}$ for NCEP and AMSR-E, and up to $20 \mathrm{~m} \mathrm{~s}^{-1}$ for winds measured on the ship.

Our findings are consistent with the previously reported results, only differing significantly from Mulcahy et al. (2008) and O'Dowd et al. (2010) for high wind speeds $\left(>10 \mathrm{~m} \mathrm{~s}^{-1}\right)$. However, we expect that the future release of the MODIS Collection 6, which takes near-surface wind speed into account when determining ocean surface reflectance, will change the conclusions reported by O'Dowd et al. (2010) in terms of reducing the wind-speed dependence in the retrieved AOD (Mishchenko and Geogdzhayev, 2007; Kleidman et al., 2012). The relationship by Mulcahy et al. (2008) overestimates aerosol optical depth, predicting AOD $\sim 0.27$ at wind speed $15 \mathrm{~m} \mathrm{~s}^{-1}$, possibly due to the breaking waves at the coastal site and only 14 measurement days contributing to the overall statistics.

As found in previous studies, there is considerable scatter in plots comparing AOD and wind speed, leading to correlations typically of order $0.3-0.5$. Our results show that the known uncertainties in the AOD and wind data used would be sufficient to degrade the observed correlation between variables, which were perfectly correlated in truth, to around 0.5 . This noise also affected the coefficients of fit, decreasing the gradient as compared with the "true" case. Thus, it is plausible that, over the remote ocean, the true strength of correlation between maritime AOD and wind speed, and the magnitude of the response, could be significantly stronger than observed in these studies.

Acknowledgements. The authors thank Hal Maring (NASA Headquarters) for his support of AERONET. The authors thank Kirk Knobelspiesse (Columbia University and NASA GISS) and anonymous reviewer for constructive comments. Measurements onboard R/V Marion-Dufresne were supported by the French Polar Institute (IPEV). NCEP Reanalysis data provided by the NOAA/OAR/ESRL PSD, Boulder, Colorado, USA, from their Web site at http://www.esrl.noaa.gov/psd/. AMSR-E data are produced by Remote Sensing Systems and sponsored by the NASA Earth Science MEaSUREs DISCOVER Project and the AMSR-E Science Team. Data are available at www.remss.com. Gert Konig-Langlo from Alfred Wegener Institute for Polar and Marine Research (Bremerhaven, Germany) is acknowledged for providing the meteorological data from R/V Polarstern. British Oceanographic Data Centre is acknowledged for providing AMT19 and 20 meteorological data (the data were supplied to BODC by Chris Barnard, Gareth Knights and Jon Seddon).

Edited by: A. Kokhanovsky

\section{References}

Adames, A. F., Reynolds, M., Smirnov, A., Covert, D. S., and Ackerman, T. P.: Comparison of MODIS ocean aerosol retrievals with ship-based sun photometer measurements from the "Around the America's” expedition, J. Geophys. Res., 116, D16303, doi:10.1029/2010JD015440, 2011.

Anguelova, M. D. and Webster, F.: Whitecap coverage from satellite measurements: A first step toward modeling the variability of oceanic whitecaps, J. Geophys. Res., 111, C03017, doi:10.1029/2005JC003158, 2006.

Blanchard, D. C. and Woodcock, A. H.: The production, concentration and vertical distribution of the sea-slat aerosol, Ann. N. Y. Acad. Sci., 338, 330-347, 1980.

de Leeuw, G., Neele, F. P., Hill, M., Smith, M. H., and Vignati, E.: Production of sea spray aerosol in the surf zone, J. Geophys. Res., 105, 29397-29409, doi:10.1029/2000JD900549, 2000.

Derber, J. C., Parrish, D. F., and Lord, S.: The new global operational analysis system at the National Meteorological Center, Weather Forecast., 6, 538-547, 1991.

Eck, T. F., Holben, B. N., Reid, J. S., Dubovik, O., Smirnov, A., O'Neill, N. T., Slutsker, I., and Kinne, S.: Wavelength dependence of the optical depth of biomass burning, urban, and desert dust aerosol, J. Geophys. Res., 104, 31333-31350, 1999.

Fan, T. and Toon, O. B.: Modeling sea-salt aerosol in a coupled climate and sectional microphysical model: mass, optical depth and number concentration, Atmos. Chem. Phys., 11, 4587-4610, doi:10.5194/acp-11-4587-2011, 2011.

Gathman, S. G.: Optical properties of the marine aerosol as predicted by the Navy aerosol model, Opt. Eng., 22, 57-62, 1983.

Glantz, P., Nilsson, E. D., and von Hoyningen-Huene, W.: Estimating a relationship between aerosol optical thickness and surface wind speed over the ocean, Atmos. Res., 92, 58-68, 2009.

Grandey, B. S., Stier, P., Wagner, T. M., Grainger, R. G., and Hodges, K. I.: The effect of extratropical cyclones on satelliteretrieved aerosol properties over ocean, Geophys. Res. Lett., 38, L13805, doi:10.1029/2011GL047703, 2011.

Haywood, J., Ramaswamy, V., and Soden, B.: Tropospheric aerosol climate forcing in clear-sky satellite observation over the oceans, Science, 283, 1299-1303, 1999.

Holben B. N., Eck, T. F., Slutsker, I., Tanre, D., Buis, J. P., Setzer, A., Vermote, E., Reagan, J. A., Kaufman, Y., Nakajima, T., Lavenu, F., Jankowiak, I., and Smirnov, A.: AERONET - A federated instrument network and data archive for aerosol characterization, Remote Sens. Environ., 66, 1-16, 1998. 
Holben, B. N., Tanre, D., Smirnov, A., Eck, T. F., Slutsker, I., Abuhassan, N., Newcomb, W. W., Schafer, J., Chatenet, B., Lavenue, F., Kaufman, Y. J., Van de Castle, J., Setzer, A., Markham, B., Clark, D., Frouin, R., Halthore, R., Karnieli, A., O’Neill, N. T., Pietras, C., Pinker, R. T., Voss, K., and Zibordi, Z.: An emerging ground-based aerosol climatology: Aerosol optical depth from AERONET, J. Geophys. Res., 106, 12067-12097, 2001.

Huang, H., Thomas, G. E., and Grainger, R. G.: Relationship between wind speed and aerosol optical depth over remote ocean, Atmos. Chem. Phys., 10, 5943-5950, doi:10.5194/acp-10-59432010, 2010.

Jaegle, L., Quinn, P. K., Bates, T., Alexander, B., and Lin, J.-T.: Global distribution of sea salt aerosols: new constraints from in situ and remote sensing observations, Atmos. Chem. Phys., 11, 3137-3157, doi:10.5194/acp-11-3137-2011, 2011.

Kahn, R. A., Gaitley, B. J., Garay, M. J., Diner, D. J., Eck, T. F., Smirnov, A., and Holben, B. N.: Multiangle Imaging SpectroRadiometer global aerosol product assessment by comparison with the Aerosol Robotic Network, J. Geophys. Res., 115, D23209, doi:10.1029/2010JD014601, 2010.

Kiliyanpilakkil, V. P. and Meskhidze, N.: Deriving the effect of wind speed on clean maritime aerosol optical properties using the A-Train satellites, Atmos. Chem. Phys., 11, 11401-11413, doi:10.5194/acp-11-11401-2011, 2011.

Kleidman, R. G., Smirnov, A., Levy, R. C., Mattoo, S., and Tanre, D.: Evaluation and wind speed dependence of MODIS aerosol retrievals over open ocean, IEEE T. Geosci. Remote, 50, 429435, doi:10.1109/TGRS.2011.2162073, 2012.

Knobelspiesse, K. D., Pietras, C., Fargion, G. S., Wang, M. H., Frouin, R., Miller, M. A., Subramaniam, S., and Balch, W. M.: Maritime aerosol optical thickness measured by handheld sunphotometers, Remote Sens. Environ., 93, 87-106, 2004.

Latham, J. and Smith, M. H.: Effect on global warming of winddependent aerosol generation at the ocean surface, Nature, 347, 372-373, 1990.

Lehahn, Y., Koren, I., Boss, E., Ben-Ami, Y., and Altaratz, O.: Estimating the maritime component of aerosol optical depth and its dependency on surface wind speed using satellite data, Atmos. Chem. Phys., 10, 6711-6720, doi:10.5194/acp-10-67112010, 2010.

Lewis, E. R. and Schwartz, S. E.: Sea Salt Aerosol Production: Mechanisms, Methods, Measurements, and Models - A Critical Review, Geophysical monograph 152, American Geophysical Union, Washington, DC, 413 pp., 2004.

Lovett, R. F.: Quantitative measurement of airborne sea-salt in the North Atlantic, Tellus, 30, 358-363, 1978.

Madry, W. L., Toon, O. B., and O'Dowd, C. D.: Modeled optical thickness of sea salt aerosol, J. Geophys. Res., 116, D08211, doi:10.1029/2010JD014691, 2011.

Melin, F., Clerici, M., Zibordi, G., Holben, B. N., and Smirnov, A.: Validation of SeaWiFS and MODIS aerosol products with globally distributed AERONET data, Remote Sens. Environ., 114, 230-250, 2010.

Meskhidze, N. and Nenes, A.: Effects of ocean ecosystem on marine aerosol-cloud interaction, Adv. Meteorol., 2010, 239808, doi:10.1155/2010/239808, 2010.

Mishchenko, M. I. and Geogdzhayev, I.V.: Satellite remote sensing reveals regional tropospheric aerosol trends, Opt. Express, 15, 7423-7438, 2007.
Morys, M., Mims, F. M., Hagerup, S., Anderson, S. E., Baker, A., Kia, J., and Walkup, T.: Design, calibration, and performance of MICROTOPS II handheld ozone monitor and Sun photometer, J. Geophys. Res., 106, 14573-14582, 2001.

Mulcahy, J. P., O’Dowd, C. D., Jennings, S. G., and Ceburnis, D.: Significant enhancement of aerosol optical depth in marine air under wind conditions, Geophys. Res. Lett., 35, L16810, doi:10.1029/2008GL034303, 2008.

O’Dowd, C., Scannell, C., Mulcahy, J., and Jennings, S. G.: Wind speed influences on marine aerosol optical depth, Adv. Meteorol., 2010, 830846, doi:10.1155/2010/830846, 2010.

O'Dowd, C. D., Lowe, J. A., and Smith, M. H.: Coupling seasalt and sulphate interactions and its impact on cloud droplet concentration predications, Geophys. Res. Lett., 26, 1311-1314, doi:10.1029/1999GL900231, 1999.

Sayer, A., Thomas, G. E., and Grainger, R. G.: A sea surface reflectance model for ATSR and application to aerosol retrievals, Atmos. Meas. Tech., 3, 813-838, doi:10.5194/amt-3-813-2010, 2010.

Sayer, A. M., Smirnov, A., Hsu, N. C., and Holben, B. N.: A pure marine aerosol model, for use in remote sensing applications, J. Geophys. Res., doi:10.1029/2011JD016689, in press, 2012.

Shinozuka, Y., Clarke, A. D., Howell, S. G., Kapustin, V. N., and Huebert, B. J.: Sea-salt vertical profiles over the Southern and tropical Pacific oceans: Microphysics, optical properties, spatial variability, and variations with wind speed, J. Geophys. Res., 109, D24201, doi:10.1029/2004JD004975, 2004.

Smirnov, A., Villevalde, Y., O’Neill, N. T., Royer, A., and Tarussov, A.: Aerosol optical depth over the oceans: Analysis in terms of synoptic air mass types, J. Geophys. Res., 100, 16639-16650, 1995.

Smirnov, A., Holben, B. N., Eck, T. F., Dubovik, O., and Slutsker, I.: Effect of wind speed on columnar aerosol optical properties at Midway Island, J. Geophys. Res., 108, 4802, doi:10.1029/2003JD003879, 2003.

Smirnov, A., Holben, B. N., Sakerin, S. M., Kabanov, D. M., Slutsker, I., Chin, M., Diehl, T. L., Remer, L. A., Kahn, R. A., Ignatov, A., Liu, L., Mishchenko, M., Eck, T. F., Kucsera, T. L., Giles, D. M., and Kopelevich, O. V.: Ship-based aerosol optical depth measurements in the Atlantic Ocean, comparison with satellite retrievals and GOCART model, Geophys. Res. Lett., 33, L14817, doi:10.1029/2006GL026051, 2006.

Smirnov, A., Holben, B. N., Slutsker, I., Giles, D. M., McClain, C. R., Eck, T. F., Sakerin, S. M., Macke, A., Croot, P., Zibordi, G., Quinn, P. K., Sciare, J., Kinne, S., Harvey, M., Smyth, T. J., Piketh, S., Zielinski, T., Proshutinsky, A., Goes, J. I., Nelson, N. B., Larouche, P., Radionov, V. F., Goloub, P., Moorthy, K. K., Matarrese, R., Robertson, E. J., and Jourdin, F.: Maritime Aerosol Network as a component of Aerosol Robotic Network, J. Geophys. Res., 114, D06204, doi:10.1029/2008JD011257, 2009.

Smirnov, A., Holben, B. N., Giles, D. M., Slutsker, I., O’Neill, N. T., Eck, T. F., Macke, A., Croot, P., Courcoux, Y., Sakerin, S. M., Smyth, T. J., Zielinski, T., Zibordi, G., Goes, J. I., Harvey, M. J., Quinn, P. K., Nelson, N. B., Radionov, V. F., Duarte, C. M., Losno, R., Sciare, J., Voss, K. J., Kinne, S., Nalli, N. R., Joseph, E., Krishna Moorthy, K., Covert, D. S., Gulev, S. K., Milinevsky, G., Larouche, P., Belanger, S., Horne, E., Chin, M., Remer, L. A., Kahn, R. A., Reid, J. S., Schulz, M., Heald, C. L., Zhang, J., Lapina, K., Kleidman, R. G., Griesfeller, J., Gaitley, B. J., Tan, 
Q., and Diehl, T. L.: Maritime aerosol network as a component of AERONET - first results and comparison with global aerosol models and satellite retrievals, Atmos. Meas. Tech., 4, 583-597, doi:10.5194/amt-4-583-2011, 2011

Villevalde, Yu. V., Smirnov, A. V., O’Neill, N. T., Smyshlyaev, S. P., and Yakovlev, V. V.: Measurement of aerosol optical depth in the Pacific Ocean and the North Atlantic, J. Geophys. Res., 99, 20983-20988, doi:10.1029/94JD01618, 1994.

Wallcraft, A.J., Kara, A. B., Barron, C. N., Metzger, E. J., Pauley, R. L., and Bourassa, M. A.: Comparisons of monthly mean $10 \mathrm{~m}$ wind speeds from satellites and NWP products over the global ocean, J. Geophys. Res., 114, D16109, doi:10.1029/2008JD011696, 2009.
Wentz, F. J. and Meissner, T.: Algorithm Theoretical Basis Document for AMSR-E Ocean Algorithms, RSS Tech Report 051707, 2007.

Zhang, J. and Reid, J. S.: A decadal regional and global trend analysis of the aerosol optical depth using a data-assimilation grade over-water MODIS and Level 2 MISR aerosol products, Atmos. Chem. Phys., 10, 10949-10963, doi:10.5194/acp-1010949-2010, 2010.

Zibordi, G., Berthon, J.-F., Mélin, F., and D'Alimonte, D.: Crosssite consistent in situ measurements for satellite ocean color applications: The BiOMaP radiometric dataset, Remote Sens. Env., 115, 2104-2115, 2011 